\title{
Timed Strategy for Control of Bollworm for Sustainable Sorghum Crop Yield under Varied Regimes of Rainfall, Temperature and Soil Fertility
}

\author{
Daniel L. Mutisya ${ }^{1}$, Canute P. M. Khamala ${ }^{2}$, Jacob J. J. O. Konyango ${ }^{3}$, Clement K. Kamau ${ }^{1} \&$ Lawrence K. \\ Matolo $^{3}$ \\ ${ }^{1}$ Kalro-Katumani. P. O. Box 340. 90100. Machakos \\ ${ }^{2}$ University of Nairobi. P. O. Box 30197. 00100. Nairobi \\ ${ }^{3}$ Machakos University College. P. O. Box 136. 90100. Machakos \\ Correspondence: Daniel L. Mutisya, Kalro-Katumani. P. O. Box 340. 90100. Machakos. \\ E-mail: dlmutisya@gmail.com
}

Received: June 27, 2016 Accepted: September 15, 2016 Online Published: October 10, 2016

doi:10.5539/sar.v5n4p71 URL: http://dx.doi.org/10.5539/sar.v5n4p71

\begin{abstract}
Various environmental factors influence yield of sorghum grain, Sorghum bicolor (L) in Sub-Sahara Africa. Various production conditions of rainfall amount, temperature regimes, soil fertility levels and bollworm Helicoverpa armigera density at specific sorghum grain stage were evaluated for effect to sorghum grain yield. High rainfall amount, high temperature and soil fertility levels were positively correlated to sorghum grain yield at three test sites at Ithookwe, Katumani and Kampi of eastern Kenya. The warmest Kampi site achieved the highest seed viability on germination test at 43,87 and $99 \%$ for grain stage of light-green, cream-dough and hard dough, respectively. High $\mathrm{H}$. armigera density was inversely correlated to grain yield. Comparatively, yield loss of $<10 \%$ was observed when grain was at early soft dough and $>35 \%$ as the grain ripened to early hard dough stage. Thus initial $H$. armigera damage occurred at late soft dough stage and increased exponentially as the grain ripened to early hard dough stage. The right time to spray against $H$. armigera was determined as at soft dough stage of sorghum grain to prevent economic damage of the crop. Thus fertility level, rainfall amount and time of bollworm pest attack were deemed worth considerations towards sustainable yield of sorghum.
\end{abstract}

Keywords: sorghum, environmental factors, soft dough, hard dough, yield

\section{Introduction}

The United States of America lead in sorghum (Sorghum bicolor L.) production with 25\% of world total of $33,963,000$ MT followed by Mexico (21\%), Nigeria (18\%), Sudan (16\%) and India (2\%) (FAO, 2016). While in the America and Asian countries the cereal has various uses in industrial and animal production sectors the same cannot be said in the African continent where the crop is mainly the second staple food after maize (Ratnavathi \& Patil, 2013). Similarly farmers in Sub-Sahara (SSA) countries continue to realize low yields of staple cereals like maize, rice and wheat (Mastersa et al., 1998; Kilambya \& Witwer, 2013). This is due to reduced and irregular rainfall patterns characterized by climate variability scenarios (Oehmke \& Crawford, 1996; Ndjeunga $\&$ Bantilan, 2005). The remedy to this could lie on production of millets and sorghum which could diversify premium incomes (Van Wajk \& Kwak, 2011). In SSA sorghum grain is a major staple in the low-income countries where in rare cases it is exported to some trade partners for foreign exchange (Ndjeunga \& Bantilan, 2005; Orr et al., 2013). Largely much relief from crop yield loss could be attained through sorghum production due to its low moisture and low nutrient requirements as well as fast development as an annual crop (Muui et al., 2013; Orr et al., 2013).

Nevertheless various production constraints exist as both biotic and abiotic factors (Fitt, 1989; Guo, 1997). These can be listed majorly as low soil fertility in marginal areas, insect damage, low yield due to low genetic potential from landraces, minimal adoptions of improved varieties, bird menace causing close to $100 \%$ grain loss in some areas and poor government policies on incentives to productions (Muui et al., 2013; Gitz III et al., 2013).

A good number of African governments are slowly addressing policy issues and farmers doing all they can to address bird menace by physically guarding crop against birds' damage though with minimal success (Oehmke 
\& Crawford, 1996; Pretty et al., 2011; Hirron et al., 2014). Other constraints of insect damage do exist where stem borers like Chilo partellus Swinhoe and Busseola fusca Fuller cause some 15-23\% crop loss in SSA where sorghum is relied upon as food security staple (van den Berg \& van Runsburg, 1991). Otherwise another insect which occur in large density during some production seasons and cause yield loss especially on white varieties is the African bollworm Helicoverpa armigera Hübner (Pedgley, 1985; Pogue, 2004; Kumar et al., 2009). A close field observation has indicated that if the arrival of the larvae worms of $H$. armigera occur during the grain ripening stage of sorghum it leads to heavy yield loss than if the grain is at dry dough (Duraimurugan \& Regupathy, 2005; Moral-Garcia, 2006). There was need to elucidate yield loss of sorghum due to H. armigera damage under specific rainfall, temperature and fertility regimes at three site plots of eastern Kenya to determine a safe time to implement control of $H$. armigera to prevent yield grain loss. Specific considerations were to be assessed: (1) at what time of grain stage a spray insecticide can be applied to prevent yield loss, (2) how much yield loss could occur if no control mechanisms are put in place. A further consideration was: (3) what other environmental factors influence and correlate to final yield like fertility, rainfall and temperature, and lead to sustainable yield achievement by farmers in marginal lands.

\section{Materials and methods}

\subsection{Sites Plot Establishment}

The field study was carried out during the short rains of October-December 2014, long rains of March-July 2015 and short rains of October 2015-January 2016 periods of production seasons. Plot sizes of $8 \mathrm{~m} \times 10 \mathrm{~m}$ were established at the sites of Katumani, Kampi-Mawe and Ithookwe of eastern Kenya. The white sorghum spacing was $60 \mathrm{~cm}$ inter-row by $25 \mathrm{~cm}$ intra-row of three plants per hill. The plots consisted of three blocks, one of insecticide treatment, one where birds were expected fed on the worms and a control in a randomized complete block design (RCBD). Bird scaring was introduced at late soft dough stage when bollworm damage peaked towards hard grain. Each of blocks had three treatments of pure sorghum, sorghum-millet alternate row and sorghum-edge rows. The insecticide used was Duduthrin ${ }^{\circledR}$ (Lambdacyhalothrin $17.5 \mathrm{~g} / \mathrm{L}$ as active ingredient of synthetic pyrethroid insecticide applied once at the rate of $200 \mathrm{ml} /$ ha three weeks after crop emergence against shoot fly and stem borers. After vegetative growth one of the blocks was sprayed with same Duduthrin® at anthesis stage of sorghum crop and repeated after seven days to prevent bollworm H. armigera. A four metre path separated the three blocks. Fertilizer application of di-ammonium phosphate (DAP) was carried out at the rate of $40 \mathrm{~kg}$ per hectare for uniform nutrition. Crop top dressing with calcium ammonium nitrate (CAN) was carried out once at the rate of $30 \mathrm{~kg} / \mathrm{ha}$ after plants attained eight leaves at the experimental sites. Weeding by hand hoe (jembe) was done three times before crop maturity during each season. The amount of rainfall (mm) during the production period was recorded for analysis and comparable production potential of sorghum at the sites. Sorghum growth development from flowering (anthesis) deep-green, light-green, light-cream, cream-white, full-cream and full grain maturity were observed for $H$. armigera density and damage on the grain among the treatments.

\subsubsection{Katumani Site}

The site at KALRO-Katumani Research Station $\left(01^{\circ} 20^{\prime} 51^{\prime \prime} \mathrm{S}, 037^{\circ} 16^{\prime} 56^{\prime \prime}\right.$ E, Elev.1609m asl) was established on a former cassava field, 11 kilometers south of Machakos Town. A yearly bimodal rainfall occurs at the site of short and long seasons respectively. Crop developmental days to grain filling, grain colour and dry dough was taken for comparative analyses between the plots. After grain yield data collection at the end of each cropping season, the field was ploughed by tractor for repeat of experiment.

\subsubsection{Kampi-Mawe Site}

The Kampi-Mawe KALRO-Sub-Centre Station is located (01 50’54” S, 037 39'29” E, Elev. 1164m asl) 10 kilometers east of Wote Town. The field had previously been planted cowpea before start of experiment in October 2014. A bimodal rainfall occurs per year at the site of short and long seasons. Data collection was carried out similar to Katumani site.

Similarly crop field was prepared by tractor for the repeat of the experiment after each season data collection.

\subsubsection{Ithookwe Site}

The Ithookwe KALRO-Sub-Centre Station is located (01 22'34" S, $037^{\circ} 58^{\prime} 43^{\prime \prime}$ E, Elev. $1147 \mathrm{~m}$ asl) three kilometers in the western side of Kitui Town. A similar bimodal type of rainfall occurs at the site like as in the above other sites. As with other sites crop developmental days to grain filling, grain colour and dry dough was taken for comparative analyses. Data collection of grain yield was taken in the same procedure as the other two fields. Likewise the crop field was prepared for next season by ploughing by tractor. 


\subsection{Soil Fertility at Sites}

The sorghum variety used for the experimental test was one being scaled up to farmers in eastern Kenya region, simply referred as "Gadam". The variety is white in colour and known by farmers as drought resistant and thrives even in low fertility areas. Soil analyses was taken in April 2016 after the experiments were ended. The aim was to determine the residual fertility conditions of the plots. At each of the sites, 10 soil samples were collected randomly across the intercrop treatment plots with soil auger at depth of $0-20 \mathrm{~cm}$ and sent to National Agricultural Laboratories of Kenya Agricultural \& Livestock Research Organization (KALRO) for nutrient element analyses on soil fertility factor suitability for sorghum production at the end of experimental period. Analyses on macro-element and micro-element nutrient levels were also scored. Residual fertility element compositions levels at each site were compared to sorghum crop requirement. The rationale here was to find out if sorghum production had been produced throughout the experimental seasons with the right fertility conditions reflected in the final yield.

\subsection{Rainfall-Temperature Effects}

Rainfall amount was recorded at each site each production season. Incidentally the three sites had functioning meteorological stations where daily records of temperature, rainfall, humidity and wind speeds were recorded. Monthly rainfall distribution and temperature regimes were averagely analyzed for site comparison. Effects of site conditions to grain yield were analyzed for comparison on insecticide applied and control plots.

\subsection{Grain Maturity and Viability}

Sorghum growth development days from flowering (anthesis) to deep-green, light-green, light-cream, cream-white, full-cream and full grain maturity were recorded. Grain samples (100 seeds) for each grain stage harvest interval were subjected to viability test of percentage germination at each specific stage and for each site plot. Net harvest sample was undertaken from three rows at the middle of the plots inclusive of all three plants (plus tillers ears).

\subsection{Grain Ripening and Bollworm Damage}

At each site grain ripening stage $H$. armigera infestation level and the resultant yield loss were correlated to elucidate the relationship. It was important to determine when highest damage occurred and recommend the right time to spray against bollworms and prevent subsequent grain loss. Some 10 randomly damaged panicle grains were compared to similar undamaged (10) heads of sorghum plants. The cumulative yield loss was expected to be different from specific interval harvest but reflective of damage at specific grain stage.

\subsection{Effect of Environmental Factors to Yield}

The effect of various environmental factors of abiotic like rain amount, temperature fluctuations and soil fertility were elucidated to explore impact to sorghum yield. Likewise bollworm damage impact to yield was determined as well the right time to spray against the insect. This would separate major production constraint in sorghum production. A multiple factor correlation was carried out to determine various factors influencing final sorghum yield.

\subsection{Data Analyses}

Analyses of variance (ANOVA) was carried to test significant difference of rainfall amounts, temperature levels, grain weight and grain yield parameters among the sites using SAS General Linear Model Procedure (GLM PROC) where Student Neumann's Keuls Post Hoc Test was used in separating the variable means. Mean nutrient element test results from the sites were comparatively analyzed for fertility levels. Multiple Linear Regression Model (MLRM PROC) was carried out to determine effect to various variables to grain yield. Correction analyses was carried out to determine effect of varied environmental factors to sorghum yield using Multiple Linear Regression Model (MLRM PROC) at 5\% level. Percentage grain maturity and viability was analyzed from 100 grains per site pooled from the 10 ears sample size per plot on each treatment.

\section{Results}

\subsection{Soil Fertility Levels}

The soil sample analyses from the three sites at the end of cropping period showed that $\mathrm{pH}$ level was within sorghum crop requirements (Table 1). As for the macronutrients Nitrogen $(\mathrm{N})$ levels were inadequately low at $0.11-0.15 \mathrm{~g} / \mathrm{kg}$ at the three sites. Ithookwe site led with the lowest levels of $\mathrm{N}$ fertility. Similarly, Phosphorous (P) was inadequately low for the crop production. Potassium, Magnesium and Calcium nutrient elements were 
adequate in the three site. The levels of the micronutrient elements of $\mathrm{Cu}, \mathrm{Fe}$, and $\mathrm{Mn}(\mathrm{mg} / \mathrm{kg})$ were assessed as adequate at Katumani and Kampi sites. At Ithookwe $\mathrm{Cu}$ was inadequately low for sorghum production. The soil texture was closely similar as loam sandy at the three sites. Overall the soil samples were found deficient of organic matter from the three sites.

Table 1. Soil fertility residual level evaluation results on sorghum plots at three sites in eastern Kenya after two year period of crop production in 2016

\begin{tabular}{ccccccccccccc}
\hline Site plot & \multicolumn{1}{c}{ Macronutrients $(\mathrm{g} / \mathrm{kg})$} & \multicolumn{4}{c}{ Micronutrients $(\mathrm{mg} / \mathrm{kg})$} & \multicolumn{3}{c}{ Soil texture (\%) } \\
& $\mathrm{pH}$ & $\mathrm{N}$ & $\mathrm{P}$ & $\mathrm{K}$ & $\mathrm{Mg}$ & $\mathrm{Ca}$ & $\mathrm{Cu}$ & $\mathrm{Fe}$ & $\mathrm{Mn}$ & Sand & Clay & Silt \\
Katumani & 5.8 & 0.15 & 0.06 & 1.0 & 2.9 & 5.0 & 42.9 & 22.0 & 0.3 & 58 & 30 & 12 \\
*Level & medium & low & low & ad & ad & ad & ad & ad & ad & & & \\
Kampi & 5.5 & 0.12 & 0.02 & 0.8 & 3.4 & 4.2 & 31.3 & 182.0 & 0.4 & 61 & 23 & 16 \\
*Level & medium & low & low & ad & hh & ad & ad & ad & ad & & & \\
Ithookwe & 5.9 & 0.11 & 0.02 & 0.5 & 2.1 & 3.4 & 23.0 & 161.0 & 0.3 & 56 & 30 & 14 \\
*Level & medium & low & low & ad & ad & ad & low & ad & ad & & & \\
\hline
\end{tabular}

Key: ad = adequate, $\mathrm{hh}=$ high: $*$ Soil nutrients diagnosis given by National Agricultural Laboratories-Kenya Agricultural \& Livestock Research Organization (KALRO)-April 2016.

\subsection{Rainfall-Temperature Effects to Yield}

Rainfall distribution within the production period indicated that Ithookwe received significantly $(P<0.0001)$ highest amount $(247 \mathrm{~mm})$ followed by Kampi $(134 \mathrm{~mm})$ (Table 2). The warmest environment was Kampi $\left(25^{\circ} \mathrm{C}\right)$ and the second being Ithookwe $\left(22^{\circ} \mathrm{C}\right)$ within a range of $21-25^{\circ} \mathrm{C}$ at the three sites. The resultant yield level was significantly $(P<0.05)$ highest at Kampi at $25.6 \mathrm{t} \mathrm{ha-}^{-1}$ while at Katumani and Ithookwe were 20.3 and $25.4 \mathrm{t} \mathrm{ha}^{-1}$, respectively.

Table 2. Level of monthly rainfall and temperature fluctuations at three sites in 2015-2016 and resultant grain yield during 3-month development period of sorghum

\begin{tabular}{lcccc}
\hline Site plot & $\begin{array}{c}\text { Monthly RF } \\
(\mathrm{mm}) \text { fluctuation }\end{array}$ & $\begin{array}{c}\text { Monthly Temp }\left({ }^{\circ} \mathrm{C}\right) \\
\text { fluctuation }\end{array}$ & $\begin{array}{c}\text { Grain wt. } \\
(\mathrm{mg})\end{array}$ & $\begin{array}{c}\text { Yield } \\
\text { Tons } / \mathrm{Ha}\end{array}$ \\
\hline Katumani & $123(14)^{\mathrm{C}}$ & $21(6)^{\mathrm{A}}$ & $2.9(0.4)^{\mathrm{A}}$ & $20.3(3.1)^{\mathrm{AB}}$ \\
Kampi & $134(16)^{\mathrm{B}}$ & $25(5)^{\mathrm{A}}$ & $3.1(0.2)^{\mathrm{A}}$ & $25.6(2.6)^{\mathrm{A}}$ \\
Ithookwe & $247(21)^{\mathrm{A}}$ & $22(4)^{\mathrm{A}}$ & $3.6(0.2)^{\mathrm{A}}$ & $25.4(2.8)^{\mathrm{B}}$ \\
$F$ & 576.9 & 0.2 & 1.6 & 3.74 \\
$P$ & $<0.0001$ & 0.9164 & 0.3248 & 0.0453 \\
\hline
\end{tabular}

Similar upper case superscript letters within columns of the four variables indicate no significant $(P>0.05)$ difference among the sites at $5 \%$ level $(d f=2,8)$-GLM PROC of SNK Test.

\subsection{Grain Maturity and Viability}

The results from the three sites showed that Kampi site had significantly $(P<0.05)$ highest level of seed viability (43\%) at the light-green grain stage with Katumani and Ithookwe at 22 and 9\% levels respectively (Table 3). Cream-dough stage at Kampi had significantly $(P<0.05)$ higher viability than the other sites. At hard dough grain stage, all the site fields indicated over $90 \%$ seed viability score.

Table 3. Sorghum grain viability (\%) index measure (and standard deviation) from milk to mature ripening stage of crop at three production sites

\begin{tabular}{lccc}
\hline Site plot & Light-green & Cream-dough & Hard dough \\
Katumani & $22(9)^{\mathrm{B}}$ & $70(6)^{\mathrm{B}}$ & $96(3)^{\mathrm{A}}$ \\
Kampi & $43(7)^{\mathrm{A}}$ & $87(6)^{\mathrm{A}}$ & $99(1)^{\mathrm{A}}$ \\
Ithookwe & $9(3)^{\mathrm{C}}$ & $48(12)^{\mathrm{C}}$ & $95(6)^{\mathrm{A}}$ \\
$F$ & 6.2 & 55.8 & 1.4 \\
$P$ & 0.0200 & 0.0004 & 0.4289 \\
\hline
\end{tabular}

Different upper case superscript letters within columns at the three sorghum grain ripening stages indicate significant $(P<0.05)$ difference at the sites at $5 \%$ level $(d f=2,8$-GLM PROC of SNK Test $)$ among the three 
treatments.

\subsection{Grain Ripening and Bollworm Infestation}

The vegetative stage to bloom took about 80 days where averagely at $83^{\text {rd }}$ day the deep-green grain stage was attained (Fig. 1). Later by $87^{\text {th }}$ day the grain turned light-green. Light-cream, full-cream, cream-white and full white seed colours were attained on 92,97, 102 and 107 days, respectively at the sites. The dry seed maturity was attained averagely at 112 days since crop establishment at the three sites for $50 \%$ of the sorghum seed.

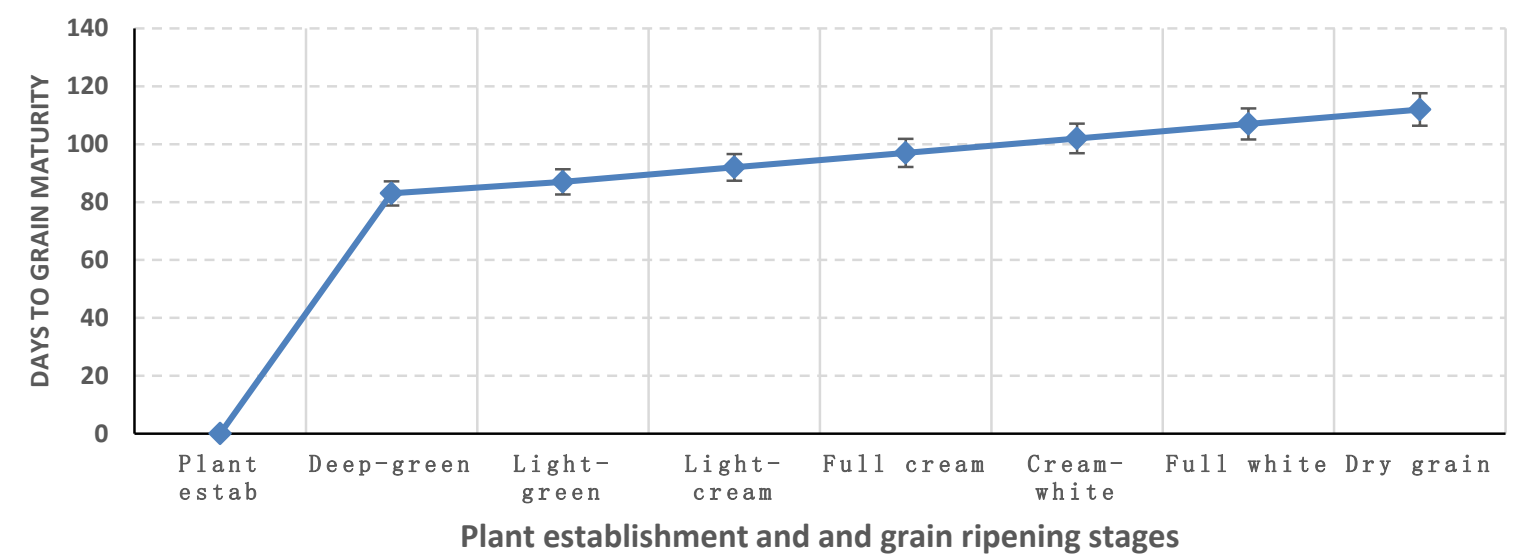

Figure 1. Mean number of days to full grain maturity stage of white sorghum crop

As the plant panicles progressed towards ripening, the insect $H$. armigera infestation levels peaked $\left(\mathrm{R}^{2}=0.5814\right)$ to 14 larvae per panicle at cream-white stage of grain with the insect feeding on the grain (Fig.2). At full-white and with decreased soft dough grain stage $H$. armigera infestations dropped to 8 larvae per plant panicle. By that time the larvae appeared to be on the fourth to sixth instar stage feeding on the grain increased. These larvae were found to be feeding on the grain and rendering the seed unviable on germination test. Our observation was that even a single larva could damage half of grains in one panicle by the time grain turned hard dough during a period of two to three weeks. The intercrop systems of millets did not show bollworm infestation difference on the plant ears. Bollworm larvae numbers did not differ between bird-fed plots and control plots.

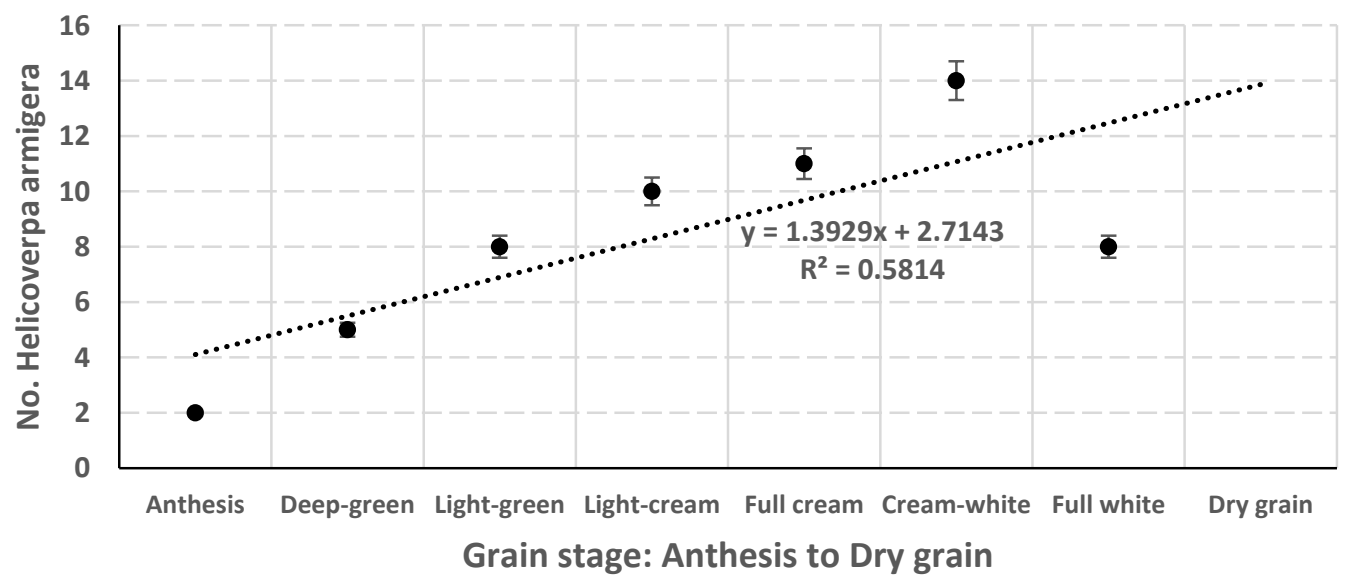

Figure 2. Helicoverpa armigera infestation on sorghum panicle towards full grain ripening stage

\subsection{Grain Damage Accumulation}

Sorghum grain damage was not visible from anthesis to deep-green with $H$. armigera density at 2-5 larvae. Grain damage visibility was from light-cream and full-cream grain stages at 5 and $10 \%$, respectively (Fig. 3). The start of dry dough stage of grain at cream-white and full-cream indicated $\mathrm{H}$. armigera density exponentially reaching $12-13$ larvae per panicle and damage level being $35-42 \%\left(R^{2}=0.8474\right)$. Comparatively the 10 panicles randomly 
sampled from the control (no insecticide spray) indicated yield loss level of $<10 \%$ when grain was at early soft dough and $>35 \%$ as the grain ripened to early dry dough stage. This was observed to be the stage when much of the grain milk sap had turned into starch (dry sap).

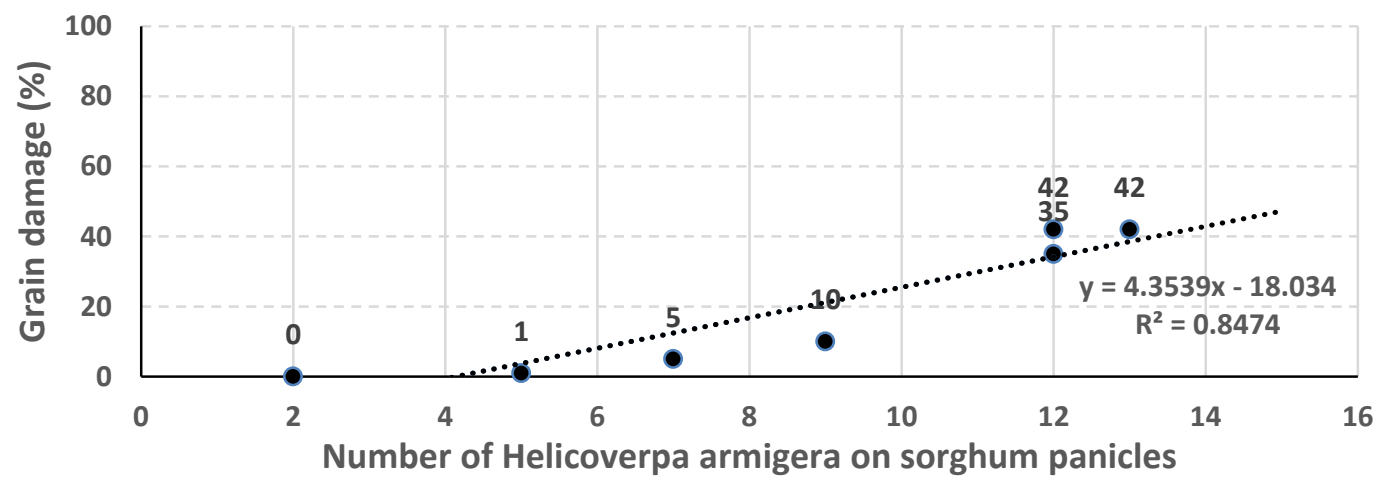

Figure 3. Damage accumulation towards grain ripening and bollworm increase on panicles of sorghum

\subsection{Effect of Environmental Factors to Yield}

Altitude was not significantly $\left(P>0.05 ; \mathrm{R}^{2}=0.0578\right)$ correlated to yield as well as the macro-nutrient elements of Nitrogen, Phosphorous and Potassium (Table 4). Other factors like soil $\mathrm{pH}$ and temperature were strongly $(P<$ $\left.0.05 ; \mathrm{R}^{2}>0.6\right)$ corrected to yield. The combined variables of rainfall $(\mathrm{mm})$ and temperature demonstrated strong $\left(P<0.05 ; \mathrm{R}^{2}=0.9817\right)$ correlation to yield. Likewise temperature-pH-rainfall combined variables indicated yet another strong correlation $\left(P<0.05 ; \mathrm{R}^{2}>0.90\right)$ between yield and environmental factors. Nevertheless bollworm density was inversely correlated to yield of sorghum grain $\left(P<0.05 ; \mathrm{R}^{2}=0.9086\right)$.

Table 4. Effects of various environmental variables to sorghum yield in Kenya eastern sites in 2015-2016

\begin{tabular}{lcccc}
\hline Variable & $\boldsymbol{t}$ & $\boldsymbol{F}$ & $\boldsymbol{R}^{2}$ & $\boldsymbol{P}$ \\
\hline Altitude $(\mathrm{m})$ & -0.50 & 0.25 & 0.0578 & 0.6464 \\
N element & 0.30 & 0.09 & 0.0215 & 0.7815 \\
P element & -0.48 & 0.23 & 0.0552 & 0.6539 \\
K element & 0.49 & 0.24 & 0.0577 & 0.6466 \\
$\mathrm{pH}$ & -2.98 & 8.88 & 0.6895 & 0.0407 \\
Temp $\left({ }^{\circ} \mathrm{C}\right)$ & 2.23 & 4.97 & 0.5541 & 0.0897 \\
$\mathrm{RF}(\mathrm{mm})$ & 1.26 & 1.58 & 0.2832 & 0.2771 \\
Temp $\left({ }^{\circ} \mathrm{C}\right) \times \mathrm{RF}(\mathrm{mm})$ & 9.55 & 80.68 & 0.9817 & 0.0024 \\
Temp $\left({ }^{\circ} \mathrm{C}\right) \times \mathrm{RF}(\mathrm{mm}) \times \mathrm{pH}$ & 0.29 & 69.31 & 0.9905 & 0.0143 \\
Bollworm density & -6.31 & 39.70 & 0.9086 & 0.0032 \\
\hline
\end{tabular}

Correlation results of above indicated independent single variable to yield at the sites ( $\mathrm{df}=1,17$ ) and two and three variables $(\mathrm{df}=1,23 ; \mathrm{df}=1,29)$ Multiple Linear Regression Model (MLRM PROC) at 5\% level.

\section{Discussion}

Results of soil analyses showed that the three sites had low inadequate macronutrients elements of nitrogen $(\mathrm{N})$ and phosphorous $(\mathrm{P})$ required for sorghum production. On the other hand potassium $(\mathrm{K})$ was reported as adequate in the three site plots. The micronutrient element compositions showed that the levels of $\mathrm{Cu}, \mathrm{Fe}$, and $\mathrm{Mn}$ were fairy adequate for sorghum production in the test sites. The three fields were low in organic matter and hence the low fertility - consequently needing manure fertilization to improve organic nutrient levels for sorghum production (Balay et al., 2002; Fornara et al., 2008). Much soil fertility requirement in crop production has been disseminated in Kenya though various assessment studies have reported low impact adoptability of such technologies due to lack of capital and low-income among farming communities (Marenya \& Barrett, 2007; Adolwa et al., 2013). Most countries in Africa suffer similar constraints of technology adoptability mainly due to little government policy on resource mobilization in the farming communities (Ajayi et al., 2007; Camara et al., 2013). 
Rainfall amount was highest $(247 \mathrm{~mm})$ at Ithookwe and the site had close similar yield (25.4 t/ha) to Kampi site (25.6 t/ ha). Gichangi et al. (2015) have demonstrated that both long and short rainfall regimes have remained average at 255 and 300mm respectively between years of 1961-2011 for eastern Kenya. The recorded levels during the present study slightly reflect above average rainfall regimes when considered cumulatively for three months production periods. Considering the low moisture requirement for sorghum the crop has low risk level for production in case of insufficient rainfall in the region. Bryan et al. (2013) have demonstrated that farmers need to weigh their options of crop enterprise with prevailing predicted rainfall patterns and plant the least risk ones like sorghum. As the climate variability continue occurring in most parts of Africa, evidently rainfall amounts are diminishing with each subsequent year and much hope for the farming communities lies with cereals like sorghum and millets and less with maize production (Tabo et al., 2007; Gichangi et al., 2015). The reason for the close similar yield levels among the two sites could be attributed to the closely related temperature regimes at Ithookwe and Kampi at $22 \pm 4{ }^{\circ} \mathrm{C}$ and $25 \pm 5^{\circ} \mathrm{C}$ respectively.

Analyzed temperature regimes since 1978 to 2011 indicate increased temperatures of $1{ }^{\circ} \mathrm{C}$ and $0.3{ }^{\circ} \mathrm{C}$ for maximum and minimum levels in eastern Kenya (Gichangi et al., 2015). These temperature increase levels are not expected to affect sorghum in most areas in Africa as the crop requires moderate similar high temperature regimes. So long as rainfall is sufficient the predicted global temperature levels rise of $4{ }^{\circ} \mathrm{C}$ will likely lead to higher sorghum yields in most areas as long as moisture levels are within optimum (Christensen et al., 2007). Various predictions of what climate variability and finally the change in short and long term effects in different regions have mostly presented a bleak future to most country economies especially in SSA (Calzadilla et al., 2013). Probably for sorghum it might not lead to such despair as with other crops like maize and wheat whose yields have been reportedly reduced by such climate variability leading to low rainfall amounts (Yegbemey et al., 2013). Pretty et al. (2011) have indicated that African agriculture growth on most crop commodities will increase with increased intensification of production factors by maximum utilization of natural resources and technical knowledge on inputs and their applications.

The final physiological maturity of the harvested grain was found related to the environmental conditions of the sites. The warmest Kampi site achieved the highest seed viability on germination test at 43,87 and $99 \%$ for grain stages of light-green, cream-dough and hard dough, respectively. Presence of bird-feeding plots did not alter infestation levels of the bollworm insect on the sorghum plants. The highest $H$. arimigera grain damage peaked exponentially at late grain soft dough (cream-white) and indicated this as the right time to spray against $H$. armigera on sorghum as pooled data from the sites showed. As for the economic injury level (EIL) we observed that even one larva of $H$. armigera could lead to serious grain damage before the grain reached hard dough stage at which no more feeding occurs. Martin et al. (2010) has recommended insecticide spray against H. zea (Boddie) in North America when an egg butch or several larvae are observed on cotton leaves. Our recommendation would be to spray immediately a single larvae is noticed on the panicles since such larva can live on the ear for over 10 days causing substantial damage as starch accumulation builds at late soft dough stage of grain (Czepak \& Albernaz, 2013). The polyphagous pest is reported to be migratory aided by heavy winds at adult stage where moths fly searching for fresh fields and has a vast diversity of host plants in east Africa (Pedgley, 1985; Mutegi et al., 2010). Species of Trichogramma genus have been cited as some of the natural enemies of H. armigera but their presence in some areas is in doubt due to other advance environmental conditions not favouring survival of the wasp (Duraimurugan \& Regupathy 2005). When H. armigera density levels reach economic injury levels other control mechanisms include use of botanical derivatives like neem or suitable chemical spray (Karim, 2000; Duraimurugan \& Regupathy, 2005). In USA and Latin America countries various chemicals have been used and exchanged after either resistant development or for environmental reasons in addition to sexual pheromone trap use (Czepak \& Albernaz, 2013). Depending on specific climatic factors like temperature and humidity, higher levels of these two could lead to higher density of $H$. armigera and hence need to monitor the pest presence frequently on sorghum ears. Sorghum fields in warm localities need insecticide spray control more frequent than cool areas as reported on cassava mite pest (Mutisya et al., 2015).

The present work has analyzed the existing factors which lead to attainment of yield levels of white sorghum, Gadam variety. The findings show that while low yield could be due to low fertility and or insufficient rainfall amounts at the production sites, other factors contribute significantly to sustainable yield of sorghum in the marginal areas. The correlation test showed that sufficient rainfall and temperature regimes led to highest yield of sorghum. To sustain the yield, control of $H$. armigera has to be carried out before dry dough grain stage, specifically at soft dough stage as the larvae start feeding on the ripening grains on the panicles. At farm level the farmer has to start with (i) adequate fertility on the production plot, (ii) some irrigation could be required where it is possible to sustain plant development and final yield in case of low rainfall amounts, and (iii) apply 
insecticide to suppress bollworm density growth early enough before economic damage occurs, otherwise temperature regimes are not expected to overshoot beyond the expected optimum levels.

\section{Acknowledgement}

We acknowledge the financial support from European Union (EU) presented by European Commission (EC) grant (CONTRACT NO.FED/2012/291-241) project name: Agricultural Productivity Research Project (APRP) and Government of Kenya (GoK) which enabled the timely carrying out of the evaluation activities at the three sites in the Counties of Machakos, Makueni and Kitui. Messrs.' Robert Mutweti, Daniel Kitheka and late Duncan Mutinda of KALRO Centers of Ithookwe, Kampi-Mawe and Katumani, respectively are acknowledged for their efforts to prepare the fields early enough for seasons' subsequent planting. Mr. Noah Mwangangi and Ms Isabel Wanza are acknowledge for yield processing and data collection. Meteorological persons serving at Kampi-Mawe (ICRISAT) Ithookwe- KALRO Sub-Centre and KALRO-Katumani in 2015-16 are acknowledged for providing climatic data of the sites.

\section{References}

Adolwa, I. S., Okoth, P. F., Mulwa, R. M., Esilaba, A. O., Mairura, F. S., \& Nambiro, E. (2012). Analysis of communication and dissemination channels influencing the adoption of integrated soil fertility management in western Kenya. The Journal of Agricultural Education and Extension, 18(1), 71-86. http://dx.doi.org/10.1080/1389224X.2012.638782

Ajayi, O. C., Akinnifesi, F. K., Sileshi, G., \& Chakeredza, S. (2007). Adoption of renewable soil fertility replenishment technologies in the southern African region: lessons learnt and the way forward. Natural Resources Forum, 31(4), 306-317. http://dx.doi.org/10.1111/j.1477-8947.2007.00163.x

Belay, A., Claassen, A. S., \& Wehner, F. C. (2002). Soil nutrient content, microbial properties and maize yield under long-term legume-based crop rotation and fertilization: a comparison of residual effect of manure and NPK fertilizers. South African of Plant Soil Journal, 19, 104-110. http://dx.doi.org/10.1080/02571862.2002.10634447

Bryan, E., Ringler, E., Okoba, B., Roncoli, C., Silvestri, S. \& Herrero, M. (2013). .Adapting agriculture to climate change in Kenya: household strategies and determinants. Journal of Environmental Management, 114, 26-35. http://dx.doi.org/10.1016/j.jenvman.2012.10.036

Calzadilla, A., Zhu, T., Rehdanz, K., Told, R. S. J., \& Ringler, C. (2013). Economy-wide impacts of climate change on agriculture in Sub-Sahara Africa. Ecological Economics, 93, 150-165.

http://dx.doi.org/10.1016/j.ecolecon.2013.05.006

Camara, B., Camara, F., Berthe, A., \& Oswald, A. (2013). Micro-dosing of fertilizer-a technology for farmers' needs and resources. International Journal of AgriScience, 3(5), 387-399.

Christensen, J. H., Hewitson, B., Busuioc, A., Chen, X. G., Held, I., Jones, R., ... Busuoic, A. (2007). Regional Climate Projections, Chap. 11. In: Solomon S, Qin D, Manning M, Chen Z, Marquis M, Averyt KB, Tignor M and Miller HL (eds). Climate Change 2007-The Physical Science Basis: contribution of working Group I to the fourth assessment report of the intergovernmental panel on Climate Change, Cambridge University Press, Cambridge, UK, pp 849-940, http://www.ipcc.ch/publications and data/ar4/wgl/en/ch11.htl.

Czepak, C., \& Albernaz, K. C. (2013). First reported occurrence of Helicoverpa armigera Hübner (Lepidoptera: Noctuidae) in Brazil. Pesquisa Agropecuaria Tropical Goiânia, 43(1), 110-113. http://dx.doi.org/10.1590/S1983-40632013000100015

Duraimurugan, P., \& Regupathy, A. (2005). Mitigation of insecticide resistance in Helicoverpa armigera (Hübner) (Lepidoptera: Noctuidae) by conjunctive use of trap crops, neem and Trichogramma chilonis ishii in cotton. International Journal of Zoological Research, 1(1), 53-58. http://dx.doi.org/10.3923/ijzr.2005.53.58

Fitt, G. P. (1989). The ecology of Heliothis species in relation to agro ecosystems. Annual Review of Entomology, 34(1), 17-52. http://dx.doi.org/10.1146/annurev.en.34.010189.000313

Food and Agriculture Organization (FAO) (2016). Sorghum production ranking. FAO Corporate Repository. www.fao.org/docrep/t08189/T0818EO3.htl

Fornara, D. A., \& Tilman, D. (2008). Plant functional composition influences rates of soil Carbon and Nitrogen accumulation. Journal of Ecology, 96, 314-322. http://dx.doi.org/10.1111/j.1365-2745.2007.01345.x

Gichangi, E. M., Gatheru, M., Njiru, E. N., Mungube, E. O., Wambua, J. M., \&Wamuongo. J. W. (2015). 
Assessment of climate variability and change in semi-arid eastern Kenya, Climate Change, 130, 287-297. http://dx.doi.org/10.1007/s10584-015-1341-2

Gitz, III D. C., Baker, J. T., Xin, Z., Lascano, R. J., Burke, J. J., \& Duke, S. E. (2013). Bird resistant pollination bags for sorghum breeding and germplasm maintenance. American Journal of Plant Sciences, 4, 571-574. http://dx.doi.org/10.4236/ajps.2013.43074

Guo, Y. Y. (1997). Progress in the researches on migratory regularity of Helicoverpa armigera and relationships between the pests and its host plants. Acta Entomologica sinica, 4, 1-6.

Hirron, M., Reuben, P., Mweresa, C. K., Ajamma, Y. O. U., Owino, E. A., \& Low, M. (2014). Crop damage despite protection efforts by human bird scares in a sorghum field in western Kenya. Journal of African Ornithology, 85, 153-159. http://dx.doi.org/10.2989/00306525.2014.937368

Karim, S. (2000). Management of Helicoverpa armigera: a review and prospectus for Pakistan. Pakistan Journal of Biological Sciences, 3(8), 1213-1222. http://dx.doi.org/10.3923/pjbs.2000.1213.1222

Kilambya, D., \& Witwer, M. (2013). Analysis of incentives and disincentives for sorghum in Kenya. Technical Note No. 17. MAFAP, FAO, Rome.

Kumar, S., Sain, S. K., \& Ram, P. (2009). Natural mortality of Helicoverpa armigera (Hubner) eggs in the cotton ecosystem. Journal of Agricultural Science and Technology, 11(1), 17-25.

Marenya, P. P., \& Barrett, C. B. (2007). Household-level determinants of adoption of improved natural resources management practices among smallholder farmers in western Kenya. Food Policy, 32(4), 515-536. http://dx.doi.org/10.1016/j.foodpol.2006.10.002

Martin, D. E., Lopez Jr., J. D., Lan, Y., Bradley, K., Hoffmann, C., \& Duke, S. E. (2010). Novaluron as an ovicide for bollworm on cotton; disposition and efficacy of field-scale aerial application. Journal of Cotton Science, 14, 99-106.

Mastersa, W. A., Bedigarb, T., \& Oehmke, J. F. (1998). The impact of agricultural research in Africa- aggregate and case study evidence. Agricultural Economics Journal, 19, 81-86. http://dx.doi.org/10.1016/S0169-5150(98)00023-1

Moral-Garcia, F. J. (2006). Analysis of the spatiotemporal distribution of Helicoverpa armigera (Hubner) in a tomato field using a stochastic approach. Biosystemic Engineering, 93(3), 253-259. http://dx.doi.org/10.1016/j.biosystemseng.2005.12.011

Mutegi, E., Sagnard, F., Muraya, M., Kanyenji, B., Rono, B., ... Labuschagne, M. (2010). Eco-geographical distribution of wild, weedy and cultivated Sorghum bicolor (L.) Moench in Kenya: implications for conservation and crop-to-wild gene flow. Genetic Resource Crop Evolution, 57, 243-253. http://dx.doi.org/10.1007/s10722-009-9466-7

Mutisya, D. L., El Banhawy, E. M., Khamala, C. P. M., \& Kariuki, C. W. (2015). Management of cassava green mite Mononychellus progresivus (Acari: Tetranychidae) in different agro-ecological zones of Kenya. Systematic \& Applied Acarology, 20(1), 39-50. http://dx.doi.org/10.11158/saa.20.1.5

Muui, C. W., Muasya, R. M., \& Kirubi, D. T. (2013). Baseline survey on factors affecting sorghum production and eastern Kenya. Journal of Food Nutrition Development, 13(1), 7339-7353.

Ndjeunga, J., \& Bantilan, M. C. S. (2005). Uptake of improved technologies in semi and tropics of West Africa. Why are agricultural transformations lagging behind? Electronic Journal of Agricultural Economics, 2(1), 85-102.

Oehmke, J. F., \& Crawford, E. W. (1996).The impact of agricultural technology in Sub-Saharan Africa. Journal of African Economics, 5, 271-92. http://dx.doi.org/10.1093/oxfordjournals.jae.a020905

Orr, A., Mwema, W., \& Mulinge, W. (2013).The value chains for sorghum beer in Kenya. International Crops Research Institute for the Semi-Arid Tropics (ICRISAT)-Series Paper No.16.

Pedgley, D. E. (1985). Windborne migration of Heliothis armigera (Hubner) (Lepidoptera: Noctuidae) to the British Isles. Entomologists Gazette, 36(1), 15-20.

Pogue, M. G. (2004). A new synonym of Helicoverpa zea (Boddie) and differentiation of adult males of $\mathrm{H}$. zea and $H$. armigera (Hubner) (Lepidoptera: Noctuidae, Heliothinae). Annual Entomological Society of America, 97(6), 1222-1226. http://dx.doi.org/10.1603/0013-8746(2004)097[1222:ANSOHZ]2.0.CO;2

Pretty, J., Toulmin, C., \& Williams, S. (2011). Sustainable intensification in African agriculture. International 
Journal of Agricultural Sustainability, 9(1), 5-24. http://dx.doi.org/10.3763/ijas.2010

Ratnavathi, C. V., \& Patil, J. V. (2013). Sorghum utilization as food. Journal of Nutrition and Food Science, 4, 247. http://dox.doi.org/10.4172./2155-9600.1000247

Tabo, R., Bationo, A., Gerard, B., Ndjeunga, J., Marchal, D., Amadou, B., \& Koala, S. (2007). Improving cereal productivity and farmers' income using a strategic application of fertilizers in West Africa. In A. Bationo, B. Waswa, J. Kihara \& J. Kimetu (Eds.), Advances in Integrated Soil Fertility Management in Sub-Saharan Africa: Challenges and Opportunities (pp. 201-208) Springer Netherlands. http://dx.doi.org/10.1007/978-1-4020-5760-1_18

Van den Berg, J., \& van Rensburg, J. B. J. (1991). Infestation and injury levels of system borers in relation to yield potential of grain sorghum. South African Journal of Plant and Soil, 8(3), 127-131. http://dox.doi.org/10.1080/0257/1862.1991.10634819

Van Wajk, J., \& Kwak, K. (2011). Beer multinationals supporting Africa's development? How partnership include smallholder into sorghum-beer supply chains. In: Van Dijk MP and Trienekens J (eds). Promoting sustainable value chains: the role of governance. Amsterdam, Amsterdam University Press, pp 71-88.

Yegbemey, R. N., Yabil, J. A., Tovignan, S. D., Gantoli, G., \& Kokoye, S. H. E. (2013). Farmers' decisions to adapt to climate change under various property rights: a case study of maize farming in Northern Benin (West Africa). Land Use Policy, 34, 168-175. http://dx.doi.org/10.1016/j.landusepol.2013.03.001

\section{Copyrights}

Copyright for this article is retained by the author(s), with first publication rights granted to the journal.

This is an open-access article distributed under the terms and conditions of the Creative Commons Attribution license (http://creativecommons.org/licenses/by/3.0/). 